\title{
The design of electric drives with electronic protection devices
}

\author{
Boris D. Khastsaev*, Larisa M. Dedegkaeva and Maksim P. Maslakov \\ North-Caucasus mining and metallurgical Institute (state technological University), Vladikavkaz, \\ Russia
}

\begin{abstract}
The possibility of designing an electronic device for protection and diagnostics of electric drives with improved characteristics is considered. The technique and algorithm of design of similar devices, the structural scheme of the device constructed on their basis are offered. To improve the characteristics of the device of protection and diagnostics of electric drives in the work it is proposed to provide for the use of measuring transducers with linear dependencies of the output values on the controlled ones. The latter is possible as a result of the use of measuring circuits in measuring transducers with linearized dependencies of the output values on the input and the use of intelligent sensors. As a measuring circuit for the construction of measuring transducers is considered the measuring circuit of Kenigsberg, which is characterized by a linear dependence of the output active value of the passive measured (controlled physical quantities). At the same time, the intelligent sensors are additionally assigned the function of linearization of the output dependence of a «simple» sensor on the controlled physical quantity.
\end{abstract}

\section{Introduction}

Timely protection and diagnostics of electric drives (ED) is important both because of the great importance of the ED, as well as because of their wide application in escalators, elevators, conveyor lines, production, etc. At the same time, known protection and diagnostic devices (PDD) for the ED are characterized by high cost, large dimensions and relatively limited functionality. Elimination of the listed shortcomings of the existing PDD relates to the actual problems, and therefore the work devoted to solving these problems is relevant.

There are many scientific works devoted to the creation of PDD for ED with new and improved functionality. Such works, for example, include the works of the last several years [1-7]. User manuals of PDDare also published for users [8]. However, all these works are insufficient, which determines the need to search for new ways and directions of development of PDD. As a result of this search, the authors investigated that among the main reasons for the shortcomings of the PDD, is the use of measuring transducers (MT) and sensors with nonlinear output characteristics. In this regard, in order to eliminate the disadvantages of PDD, it is proposed to use as part of the MT, on the basis of which the PDD is based, as

${ }^{*}$ Corresponding author: bordsamchas@rambler.ru 
measuring circuits with linear output characteristics, and electronic sensors with linearized output characteristics (it is possible to use intelligent sensors). This way determines the novelty of the work and provides a significant increase in the reliability of information about the state of all parts of the ED and the efficiency of the work of the PDD.

Recall that the most well-known types of ED protection are associated with the protection of the engine from short-circuit, over-current, thermal overload, idling and breakage phases, phase bias currents, violations of the power supply network, single-phase earth fault, the minimum voltage, the minimum current, the reverse power. The protection function also includes monitoring the insulation resistance, heating of the motor, the ingress of water, the treatment of external alarms, etc.Even such a simple list of protection functions determines the importance of the development of PDD with improved characteristics, at the same time it shows the complexity of the tasks to be solved.

\section{Theoretical part}

The analysis of existing literature sources allowed to choose the most promising way to improve the properties and capabilities of PDD, providing design of PDD for electronic control systems based on linear MT and electronic sensors with linearized characteristics or intelligent sensors. The perspective of the path is determined by the fact that the MT together with the sensors participate in the formation of primary information about all the nodes of the ED, for example, about the heating of the engine, about the deviations of the electric power, etc. Therefore, the effectiveness of PDD for ED largely depends on the reliability of information provided by MT.

Hence, the high importance of the way to improve the PDD, providing for the use of MT with improved characteristics in the composition of the PDD and the use of sensors with improved properties and capabilities. This way provides a higher accuracy of measurement of controlled quantities coming from the sensors, obtaining more reliable information about the state of the ED nodes, and therefore, the construction of PDD with improved characteristics.

Of the variety of sensors that solve the problem of protection of the ED, consider only a few electronic sensors-temperature sensors, which transform functions, as well as other sensors, nonlinear. For these sensors, the dependence of resistance on temperature is different, which still depends on the temperature coefficient of resistance $\alpha$ [14]. Data on sensors are shown in the Table 1.

Table 1. Examples of temperature sensors and their characteristics

\begin{tabular}{|c|c|c|c|c|}
\hline Sensor type & $\begin{array}{c}\text { The value of the } \\
\text { temperature } \\
\text { ratio } \alpha\end{array}$ & $\begin{array}{c}\text { Measuringrange } \\
\text { temperatures }\end{array}$ & $\begin{array}{c}\text { The form of the transformation } \\
\text { function }\end{array}$ & $\begin{array}{c}\text { Values } \\
\text { constant coefficient }\end{array}$ \\
\hline \multirow{2}{*}{$\begin{array}{l}\text { Platinum } \\
\text { thermal } \\
\text { resistance } \\
\text { (TR) }\end{array}$} & \multirow[b]{2}{*}{$0,00385^{\circ} \mathrm{C}^{-1}$} & $-200^{\circ} \mathrm{C}$ до $0^{\circ} \mathrm{C}$ & $\mathrm{R}_{\mathrm{l}}=\mathrm{R}_{0}\left[1+\mathrm{At}+\mathrm{Bt}^{2}+\mathrm{C}\left(\mathrm{t}-100^{\circ} \mathrm{C}\right) \mathrm{t}^{3}\right]$ & \multirow{2}{*}{$\begin{array}{l}\mathrm{A}=3,9083 \cdot 10^{-3}{ }^{\circ} \mathrm{C}^{-1} \\
\mathrm{~B}=-5,775 \cdot 10^{-7}{ }^{\circ} \mathrm{C}^{-2} \\
\mathrm{C}=-4,183 \cdot 10^{-12}{ }^{\circ} \mathrm{C}^{-4}\end{array}$} \\
\hline & & от $0^{\circ} \mathrm{C}$ до $850^{\circ} \mathrm{C}$ & $\mathrm{R}_{\mathrm{t}}=\mathrm{R}_{0}\left(1+\mathrm{At}+\mathrm{Bt}^{2}\right)$ & \\
\hline \multirow{2}{*}{$\begin{array}{l}\text { Platinum } \\
\text { TR }\end{array}$} & \multirow{2}{*}{$0,00391{ }^{\circ} \mathrm{C}^{-1}$} & $-200^{\circ} \mathrm{C}$ до $0^{\circ} \mathrm{C}$ & $\mathrm{R}_{\mathrm{t}}=\mathrm{R}_{0}\left[1 \mathrm{At} \mathrm{Bt}^{2} \mathrm{C}\left(\mathrm{t} 100^{\circ} \mathrm{C}\right) \mathrm{t}^{3}\right]$ & \multirow{2}{*}{$\begin{array}{l}\mathrm{A}=3,9690 \cdot 10^{-3}{ }^{\circ} \mathrm{C}^{-1} \\
\mathrm{~B}=-5,84 \cdot 10^{-7}{ }^{\circ} \mathrm{C}^{-2} \\
\mathrm{C}=-4,330 \cdot 10^{-12}{ }^{\circ} \mathrm{C}^{-4}\end{array}$} \\
\hline & & от $0^{\circ} \mathrm{C}$ до $850^{\circ} \mathrm{C}$ & $\mathrm{R}_{\mathrm{t}}=\mathrm{R}_{0}\left(1+\mathrm{At}+\mathrm{Bt}^{2}\right)$ & \\
\hline \multirow{2}{*}{ Copper TR } & \multirow{2}{*}{$0,00428^{\circ} \mathrm{C}^{-1}$} & $-180^{\circ} \mathrm{C}$ до $0^{\circ} \mathrm{C}$ & $\mathrm{R}_{\mathrm{t}}=\mathrm{R}_{0}\left[1+\mathrm{At}+\mathrm{Bt}\left(\mathrm{t}+6,7^{\circ} \mathrm{C}\right)+\mathrm{Ct}^{3}\right.$ & \multirow{2}{*}{$\begin{array}{c}\mathrm{A}=4,28 \cdot 10^{-3}{ }^{\circ} \mathrm{C}^{-1} ; \\
\mathrm{B}=-6,2032 \cdot 10^{-7}{ }^{\circ} \mathrm{C}^{-2} \\
\mathrm{C}=8,5154 \cdot 10^{-100} \mathrm{C}^{-3}\end{array}$} \\
\hline & & $0^{\circ} \mathrm{C}$ до $200^{\circ} \mathrm{C}$ & $\mathrm{R}_{\mathrm{t}}=\mathrm{R}_{0}[1+\mathrm{At}]$ & \\
\hline \multirow[b]{2}{*}{ Nickel TR } & \multirow[b]{2}{*}{$0,00617^{\circ} \mathrm{C}^{-1}$} & $-60^{\circ} \mathrm{C}$ до $+100^{\circ} \mathrm{C}$ & $\mathrm{R}_{\mathrm{t}}=\mathrm{R}_{0}\left(1+\mathrm{At}+\mathrm{Bt}^{2}\right)$ & \multirow{2}{*}{$\begin{array}{l}\mathrm{A}=5,4963 \cdot 10^{-30} \mathrm{C}^{-1} ; \\
\mathrm{B}=6,7556 \cdot 10^{-60} \mathrm{C}^{-2} ; \\
\mathrm{C}=9,2004 \cdot 10^{-9}{ }^{\circ} \mathrm{C}^{-3}\end{array}$} \\
\hline & & $+100^{\circ} \mathrm{C}$ до $180^{\circ} \mathrm{C}$ & $\mathrm{R}_{\mathrm{t}}=\mathrm{R}_{0}\left[1+\mathrm{AtBt}+\mathrm{C}\left(\mathrm{t}-100^{\circ} \mathrm{C}\right) \mathrm{t}^{2}\right]$ & \\
\hline
\end{tabular}


Since the purpose of this work is to design the PDD with new properties and capabilities, the linearized measuring circuit of Kenigsberg (CK) is chosen for the development of the MT [13]. This circuit is shown in fig.1, and its transformation function has the form:

$$
\mathrm{U}_{\mathrm{O}}=\mathrm{U}_{\mathrm{S}}\left(\frac{Z 1}{Z 2}-\frac{Z 3}{Z 4}\right)
$$

where: Z1, Z2, Z3, Z4 are the impedances of the branches of the CK; $\mathrm{U}_{\mathrm{O}}$ - the output voltage of the bridge circuit; $U_{S}$ - the supply voltage of the bridge circuit.

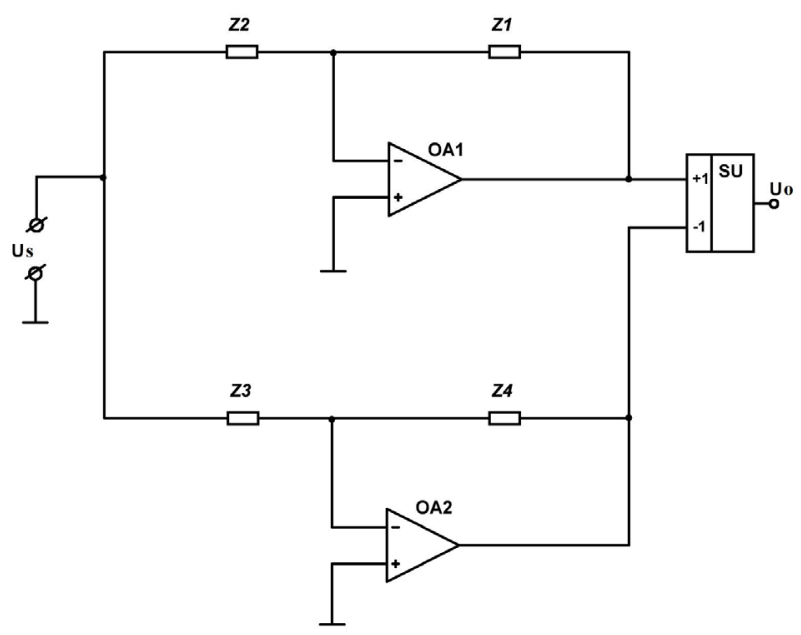

Fig. 1. The measuring circuit of Kenigsberg (bridge AC)

From (1) the linear dependence of the output value on the impedance Z1, Z3 and the inverse impedance Z2, Z4 is seen. The change of any of the impedances Z1, Z3 or any of the inverse values of the impedances $Z 2, Z 4$ can represent valuable information about the controlled physical quantities. For the sake of brevity, we note that the Kenigsberg measuring circuit is implemented on the basis of two operational amplifiers OA1, OA2 and on the basis of the summing block SU.CK refers to AC bridges. Control variables Z3, Z4 of the measuring circuit can lead in quasi-balanced or in zero state of.

\section{Method of design of PDD}

The proposed method of design of PDD provides the following:

- selection of all types of protection all or the most important for the selected application of the ED;

- prioritization for each selected type of protection;

- the use of borrowed or their own techniques for designing;

- development of PDD model taking into account the selected types of protection and additional requirements for PDD;

- selection and justification of the structure of PDD based on the analysis of known technical solutions;

- optimization of PDD and its individual nodes;

- selection of the element base for the implementation of PDD;

- development of the circuit diagram of PDD. 
On the basis of these points, an algorithm for computer-aided design of PDD was developed, presented in fig.2, which shows the main stages of design.

Without dwelling on the consideration of these stages, as well as on the analysis of the selected design principles and their relationship with the stages, we note only the main features of the PDD design process. Thus, the search for new approaches to the design of PDDs based on the analysis of modern circuit solutions, showed that the technical characteristics of PDDs can be significantly improved by building them on the basis of microcontrollers. In addition, it was concluded that the emergence of PDD with improved functionality and, at the same time, with a reasonable price leads to a new round of growth of applications of PDD, and therefore to an increase in demand for these devices.

Analysis of applications of ED and define the requirements for the PDD for the selected areas, the formulation of the design purpose

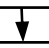

Selection of the most priority and appropriate protection functions for the ED, providing wide application of the ED with PDD

\section{$\downarrow$}

Development of PDD model and its separate blocks, computer research of the developed models

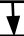

Development of the block diagram of the PDD based on the analysis of the

known technical solutions, the choice of the MC with the linearized circuit

Correction of design purpose and requirements to the developed PDD, selection of sensors with linearization of output characteristics
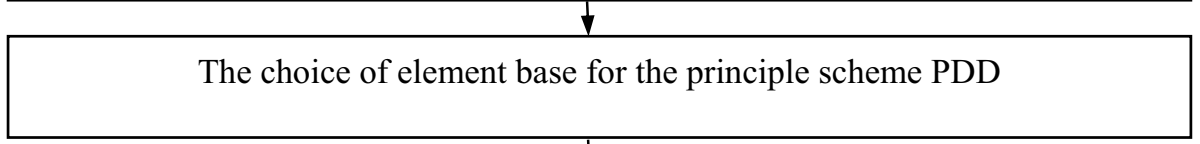

$\frac{1}{1}$

Development of the principle scheme PDD

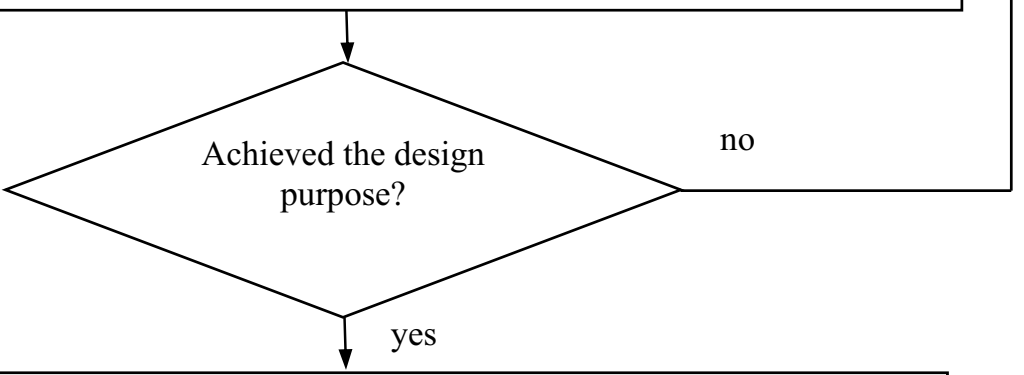

The procedure of optimization concepts PDD

Fig. 2. The algorithm design of the PDD for ED

The choice of a microcontroller for PDD creation determines such PDD capabilities as digital data processing, archiving, storage, reporting and measurement Protocols, the use of 
artificial intelligence. Also, the microcontroller provides: increased measurement accuracy, digital display of measurement results, communication with a computer top level, etc. It follows that the use of the microcontroller in PDD leads to a significant expansion of its functionality.

\section{A generalized structure scheme of the electronic PDD for ED}

On the basis of the analysis of the works devoted both to protection of ED from emergency situations, and diagnostics of ED, the generalized structure schemeof electronic PDD given on fig.3. As can be seen from this figure, the main elements of the PDD scheme are: the ED itself with the block of actuating mechanisms (BAM); the block of sensors (BS) or sensing elements used in the ED to control the monitored physical quantities; the block of measuring converters (BMC) with a bridge converter (BC) necessary to convert the sensor signals into unified electrical quantities and in which, as recommended, the CK is used; data acquisition unit (DAU) with ainformation display module (IDM) used for collecting and processing the measurement results, as well as for displaying information; block interfase (BI), which provides connection of the device with other devices $[11,12]$.

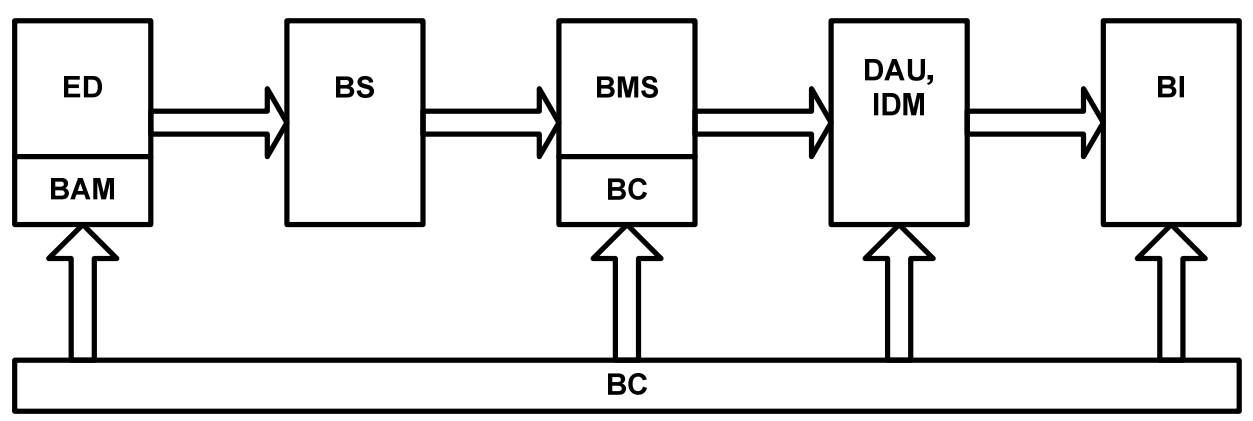

Fig. 3. A generalized structure scheme of the electronic PDD for ED

\section{The requirements for $C K$ used in the proposed PDD}

The Kenigsberg circuit in PDD is primarily designed to work in conjunction with temperature sensors (for example, with resistance thermometers). The next purpose of the $\mathrm{CK}$ is determined by the possibility of connecting it to the selected section of the motor winding, in which the conversion of the active and inductive components of the impedance of the winding section should be provided or a check for the winding break should be provided. Other applications of $\mathrm{CK}$ are possible. Thus, when measuring the temperature at different parts of the $\mathrm{ED}$, the input value $\mathrm{CK}$ is the change in the electrical impedance of the temperature sensor, and when measuring the impedance at different parts of the winding, the change in the components of the impedance at the selected part of the ED winding. As can be seen, in all cases of $\mathrm{CK}$ application it is necessary to convert an informative signal in the form of impedance change into an electric unified signal. It is important to note once again that the sensors used have nonlinear output characteristics, so the problem of linearization of their transformation functions is solved in different ways.It is possible to use intelligent sensors with linearization of sensor conversion functions.

It is most appropriate to use MT operating in the quasi-balancing mode [6]. Studies have confirmed that CK allows to build: simple MT with analog balancing; MT converting various parameters of the impedance of the objects under control, etc. 


\section{Conclusion}

The paper proposes a new and promising way of designing PDD for ED providing an increase in the degree of protection of ED and provides for the use of PDD measuring transducers with linearized dependencies of the output values of the measured values. At the same time, the path provides for the use of intelligent sensors in $\mathrm{MC}$ with the function of linearization of the sensor output value depending on the measured value.

The fulfillment of the conditions of the proposed path provides a significant increase in the accuracy of measurement of controlled quantities, and hence-the early elimination of accidents in the ED, the expansion of the application areas of both the PDD and the ED. The technique and algorithm of design of electronic PDD with improved characteristics, on the basis of which the generalized structural scheme of PDD providing protection and diagnostics of ED with greater reliability, than analogs is constructed.

The work is of great interest for researchers, postgraduates to develop experimental facilities, and for developers of electronic equipment.

\section{References}

1. M.M. Kikmetov, Sovershenstvovanie zashit asinkhronnykh electrodvigatelei 0,4 $\mathrm{kW}$ otperegruzki, Avtoreferat dissertacii (Krasnodar, 2003)

2. T.A. Glazyrina, Materialy IV mejdynarodnoi naushno-texnisheskoi konferenzii, Pavlodar, 132 (2010)

3. O.A. Philichev, N.D. Pozdeev, Ustroistvo dlya zashity trekhfaznykh asinkhronnykh dvigatelei, Patent RFRU №2415504 C2, MPKH02H 7/08 (2011)

4. T.A. Glazyrina, Elektromexanisheskie preobrasovateli ehergii: materialy V Yubileinoi mejdynarodnoi naushno-texnisheskoi konferenzii (2011)

5. V.F. Sivokobylenko, S.N. Tkashenko, Naukovi praci Donec'kogo nacial'nogo tekhnicheskogo universitetu, 11(186), 353 (2011)

6. T.A. Glazyrina, Sovershenstvovanie metodov diagnostiki asinkhronnyh dvigatelej na osnove analiza potreblyaemyh tokov, Avtoreferat dissertazii na soiskanie uchenoj stepeni kandidata tekhnicheskih nauk. (Tomsk, 2012)

7. S.V. Mihalev, Sistema podderzhki ustojchivosti raboty sinkhronnyh ehektrodvigatelej 6$10 \mathrm{kV}$, Dissertaciya na soiskanie uchenoj stepeni kandidata tekhnicheskih nauk (SankPeterburg, 2014)

8. Ustrojstvo zashchity dvigatelya UZD, Rukovodstvo po ehkspluatazii GSPK. 468263.129 REH. OOO NTF «Mikroniks», 34 (2013)

9. I.O. Marchenko, Sistema proektirovaniya mnogofunkcional'nyh rekonfiguriruemyh intellektual'nyh datchikov, Dissertaziya na soiskanie uchenoj stepeni kandidata tekhnicheskih nauk, (Novosibirsk, 2015)

10. O.V. Shishov, FGBOUVPO «Mordovskijgosudarstvennyjuniversitetim. N. P. Ogareva» http://fetmag.mrsu.ru/2011-2/pdf/smart_sensors.pdf.

11. B.D. Khastsaev, L.M. Dedegkaeva,A.L. Korolev, A.I. Abaev, Science and Technology, 2,14 (2016)

12. B.D. Khastsaev, V.A. Sozaev, A.L. Korolev, V.A. Kodzasov, Science and Technology, 2, 22 (2016)

13. M.A. Gavrilyuk, E.P. Sogolovskij, Chetyrekhplechiemostyperemennogotoka («Vishchashkola», L’vov, 1975)

14. https://elquanta.ru/teoriya/termosoprotivlenie.html 